\title{
Evaluation of a Pilot Healthy Eating and Exercise Program for Young Adults with Autism Spectrum Disorder and Intellectual Disabilities
}

\author{
Laura Nabors $^{1} \mathbb{D} \cdot$ Abby Overstreet $^{1} \cdot$ Christina Carnahan $^{2} \cdot$ Kara Ayers $^{3}$
}

Accepted: 12 August 2021 / Published online: 25 August 2021

(C) The Author(s), under exclusive licence to Springer Nature Switzerland AG 2021

\begin{abstract}
Objectives The aims of this pilot study were to examine program structure, implementation, and outcomes of a healthy eating and exercise program for young adults with Autism Spectrum Disorder (ASD) and intellectual disabilities (IDs).

Methods Seventeen young adults with ASD and IDs, six parents, and 10 staff participated. Programming was delivered for over a year and featured healthy eating and exercise lessons. Also, group-based motivational interviewing was used to develop weekly health goals for participants. During COVID-19, lessons were delivered online. The program was modified using lectures with visual material, when participants returned to classrooms. Lessons focused on MyPlate, portion sizes, the food pyramid, vitamins and minerals in foods, and learning to eat "less" of unhealthy food groups. Exercise lessons featured information about importance of exercise, introduction to different types of exercise, and knowledge about how exercise benefits the body. Staff completed implementation logs. Height and weight of participants were examined at regular intervals. Parents completed surveys and participants completed group interviews to assess program impact.

Results Two participants lost a significant amount of weight and others maintained their weight during COVID-19. Participants and parents were satisfied with the program and reported knowledge and behavior change.

Conclusions Results indicated participating in the intervention resulted in improved knowledge and health behaviors. Findings are preliminary, and research using control groups and assessing change in weight and behaviors over time are needed. Observation of meals and physical activity levels will provide more objective data in future studies.
\end{abstract}

Keywords Autism Spectrum Disorder · Intellectual disabilities · Obesity management $\cdot$ Healthy eating · Exercise $\cdot$ COVID19

Young adults with Autism Spectrum Disorder (ASD) and intellectual disabilities (IDs) are at risk for being overweight or obese (Hsieh et al., 2014; Li et al., 2020; Zheng et al., 2017). They may face higher levels of health risks for cardiovascular disease, sleep problems, gastrointestinal problems,

Laura Nabors

naborsla@ucmail.uc.edu

1 Health Promotion and Education Program, School of Human Services, College of Education, Criminal Justice and Human Services, Mail Location 0068, 2610 McMicken Circle, CECH, University of Cincinnati, Cincinnati, OH 45221-0068, USA

2 Special Education Program, School of Education, College of Education, Criminal Justice and Human Services, University of Cincinnati, Cincinnati, OH, USA

3 Division of Developmental and Behavioral Pediatrics, Cincinnati Children's Hospital Medical Center, Cincinnati, $\mathrm{OH}, \mathrm{USA}$ and type 2 diabetes (Croen et al., 2015; Davignon et al., 2018; Ptomey et al., 2020). For many young adults with ASD and ID, being overweight is related to unhealthy eating and a sedentary lifestyle (Hsieh et al., 2014; Zheng et al., 2017). Improving engagement in physical activity along with reducing calorie intake can reduce obesity (Draheim et al., 2002). However, due to a lack of accessible education about healthy living, limited opportunities for physical activity, and resistance to changing eating habits, it may be difficult for young adults with ASD and ID to lose weight. Interventions for young adults with developmental disabilities have shown success in improving health, changing eating patterns, and facilitating weight loss (e.g., Bedard et al., 2021; Myers et al., 2018; Shlesinger et al., 2018; Singh et al., 2008).

Healthy eating and exercise programs focusing on the Traffic Light diet and design of healthy meals have met with some success in changing behaviors and facilitating weight 
loss for young adults with IDs (e.g., Harris et al., 2017; Melville et al., 2011; Ptomey et al., 2015). For example, Ptomey et al. (2015) compared the effectiveness of the Traffic Light Diet (Epstein, 2005) to a conventional diet approach for weight loss for adolescents with IDs. Youth were randomly assigned to participate in the Traffic Light Diet education or the conventional diet group. Youth and caregivers in both groups worked with registered dieticians via video chat on a tablet weekly to receive education about diet and physical activity. Participants tracked diet on the tablet. They attended about $80 \%$ of video chats. The Traffic Light Diet involves education about red food (high fat/high calorie), which are consumed once in a while; yellow foods (lower in fat/calories), such as whole-wheat bread, pasta, which are consumed sometimes; and green foods (low fat/low calorie), such as fruits and vegetables, which are consumed frequently. A goal is to eat more green foods, some yellow foods, and limit the intake of red foods. Tablets were used to deliver educational information about the Traffic Light Diet, and parents/caregivers were involved in lesson planning. A positive change in weight was found for both groups, and both the Traffic Light Diet education group and the conventional diet group showed about the same level of success, with each group losing about 2-3 kg (about 4-6 lbs). Ptomey et al. (2015) reported that tablets were effective for education and offered a way to reach more youth and parents.

In later research, Ptomey et al. (2018) reported that although the Traffic Light Diet (Epstein, 2005) was an effective educational tool, there could be difficulty implementing the approach, if red foods were used as rewards/ prizes for positive behaviors. They recommended conducting further research to understand if the Traffic Light Diet would be successful for educating about healthy eating and weight loss, when other behavioral health programming was being used to improve emotional and behavioral functioning of youth with IDs. Also, it is important to determine if the Traffic Light Diet is viable for young adults, as this program was initially developed for children. Weems et al. (2017) reported individuals with IDs may have difficulty distinguishing between foods that they can have once in a while (e.g., red foods) and those that they can have often (e.g., green foods). Understanding how to provide education to increase comprehension of foods to consume daily (e.g., fruits and vegetables) and those to consume occasionally (e.g., cake) is an important component of educational messaging. Grumstrup and Demchak (2017) recommended that researchers use pictures and live presentations to teach skills, teaching reasons or cause and effect of health behaviors, and prioritizing activities that individuals enjoyed and could perform with their families.

Melville et al. (2011) developed the multi-component TAKE 5 Program to improve weight loss of adults with IDs who were obese. This multi-component program involved cutting calories (about 600 per day), implementation of educational programming (featuring learning about food groups [Eatwell Plate] and portion sizes), goal setting (with caregivers, parents, and the participants), and increasing physical activity. Lessons, focusing on healthy eating and exercising 30 min five times per week, were provided individually, every $2-3$ weeks, for a total of nine sessions. Health professionals worked with caregivers and changed participants' dietary intake. Similarly, health professionals, who worked with parents/caregivers to determine a healthy eating and exercise goal with parents/caregivers, presented the goal to participants, and the parents/caregivers and participants attempted to reach goals by the next session. Melville et al. (2011) found that approximately $35 \%$ of their participants (47 completed the program) lost $5 \%$ of their body weight. Melville et al. (2011) also reported improved engagement in light physical activity (e.g., engaging in housework, walking), but not changes in moderate to vigorous activity.

Harris et al. (2017) compared the TAKE 5 Program to a health education program (Waist Winners Too). Both programs were accepted by individuals with IDs (90\% retention rates). The TAKE 5 Program used pedometers for individuals to track involvement in PA and dietary change (reducing calorie intake), and these were key differences from the health education program. Nine to twelve individual sessions were delivered and a dietician was involved in program delivery. Results indicated that the TAKE 5 Program was more effective in achieving weight loss (5-10\%) at six- and 12-month follow-up assessments compared to the health education program. There was not a change in levels of physical activity, however, and Harris et al. (2017) recommended focusing on changing home-based activities and prompting activity between sessions. Harris et al. (2017) conducted a randomized controlled trial, and had a dietician on staff. They proposed that a health education program was not effective, but that is typically what is available in many community settings, where it may not be feasible to change individuals' diets. Also, many community-based programs do not have a dietician available and do not have funding for pedometers.

Additionally, in community programs, it may not be feasible to hold individualized sessions with participants. It may be that the health education programming would meet with some success were it longer in duration, with more of an emphasis on exercise and self-determination of eating and exercise change. Self-determination may be effective in fostering independence and behavior change in individuals with disabilities, and is a central tenet in the program within which this pilot study was conducted (Burke et al., 2020; Gelbar et al., 2020; Shogren et al., 2019). Rather than individual programming, health education can be delivered in groups, with a group-based motivational interviewing (MI) approach (Miller \& Rollnick, 
2002). If young adults select their own health goals, they may be more invested in attaining them or the goals may reflect their own preferences, also increasing chances goals will be achieved. Moreover, shaping a program, based on participant, staff, and caregiver feedback, also may improve uptake of the program, and feedback from stakeholders may ensure the program shifts to meet evolving needs and program changes.

Interventions promoting agency and providing choices can empower young adults. Considering the value of choice is critical in obesity treatment (e.g., Carr \& Epstein, 2020). MI is non-confrontational and a non-judgmental method for developing goals to slowly improve behaviors (Miller \& Rollnick, 2002). This method can be especially helpful with those who are ambivalent about making changes (LaBrie et al., 2007), and young adults with ASDs and IDs often resist change. A systematic review indicated some promise for MI in improving adherence to recommendations for youth with chronic medical conditions (Schaefer \& Kavookjian, 2017). Group-based MI also has the potential to improve adherence to recommendations in adults (Abughosh et al., 2019), but to our knowledge has not been used in programs to promote healthy eating and exercise for individuals with ASD and IDs.

This evaluation is rooted in a quality assurance framework (Donabedian, 1966). The goal of our quality assurance process was to use assessment procedures that would obtain information about the structure and process of our intervention and information about outcomes, including weight loss and perceptions of programming (Donabedian, 1966). The aims of this evaluation were fourfold. The first was to describe program implementation. Second, we describe our evaluation process (methods of obtaining information and results) and changing methods to "match" the needs and abilities of participants. Third, we describe the implementation of the program, including feedback from the staff and administrators. Fourth, we present the results of our program.

\section{Methods}

\section{Participants}

Seventeen young adults (seven females and ten males) with ASDs and IDs, diagnosed by clinicians and receiving services for developmental disabilities, and their parents/ caregivers (five females/1 male) participated. Young adults were attending educational programming in a unit for adults with ASD and IDs at a large midwestern university. Ten college students (four females and six males), who were staff from the program, provided information about program delivery.

\section{Procedures}

Young adults participated in weekly lessons about healthy eating, exercise, and health topics (such as stress reduction and healthy sleep) related to overeating. Table 1 presents healthy eating lessons by trimester. Services were provided from January of 2020 through April of 2021.

From January of 2020 through March of 2021, health education programming was provided in small groups, with health educators working individually with participants. Programming featured information on the Traffic Light Diet (Epstein, 2005). Lessons reviewed the traffic light foods, with "red" (high calorie, high fat, like ice cream), "yellow" (lower in calories and fat, such as pasta and bread), and "green" foods (e.g., fish, fruits, vegetables). Educators encouraged participants to get their "4-1-1"- trying to eat four green foods for every one yellow and red food. Participants learned about types of foods, in different food groups, and whether they were red, yellow, or green foods. Moreover, health educators exercised with participants at the college recreation center and worked with participants on exercises recommended by a physical therapist. The program was suspended with the COVID-19 pandemic from April through May of 2020. During this time, a parent contacted the team and stated that her young adult reported confusion about the colors of foods in the Traffic Light and their relation to "red, yellow, and green foods." The young adult was getting confused with the Traffic Light Diet (Epstein, 2005), due to the colors of foods and the colors on the stoplight. For instance, apples are red so they could be a "red" food. Also, the staff at the program indicated the behavioral management system included a stoplight, and having a stoplight for a healthy eating image could be confusing. Thus, the team stopped using the Traffic Light Program.

Services for participants resumed in June through the second week of August with small groups meeting using Microsoft Teams ${ }^{\circledR}$. Parents attended meetings with students. The team changed the intervention to lessons featuring MyPlate, the food pyramid, and teaching about portions of foods appropriate for young adults to eat (see Table 1). In terms of exercise, walking and exercises that could be accomplished at home were selected, and goal setting continued. The health educator met with participants once a week.

From mid-August 2020 through April of 2021, meetings were delivered in the classroom, with young adults, in small groups. Participants were in small groups or pods and remained in their group and room each day. Young adults and the evaluation team wore masks and followed social distancing protocols established by the university. 


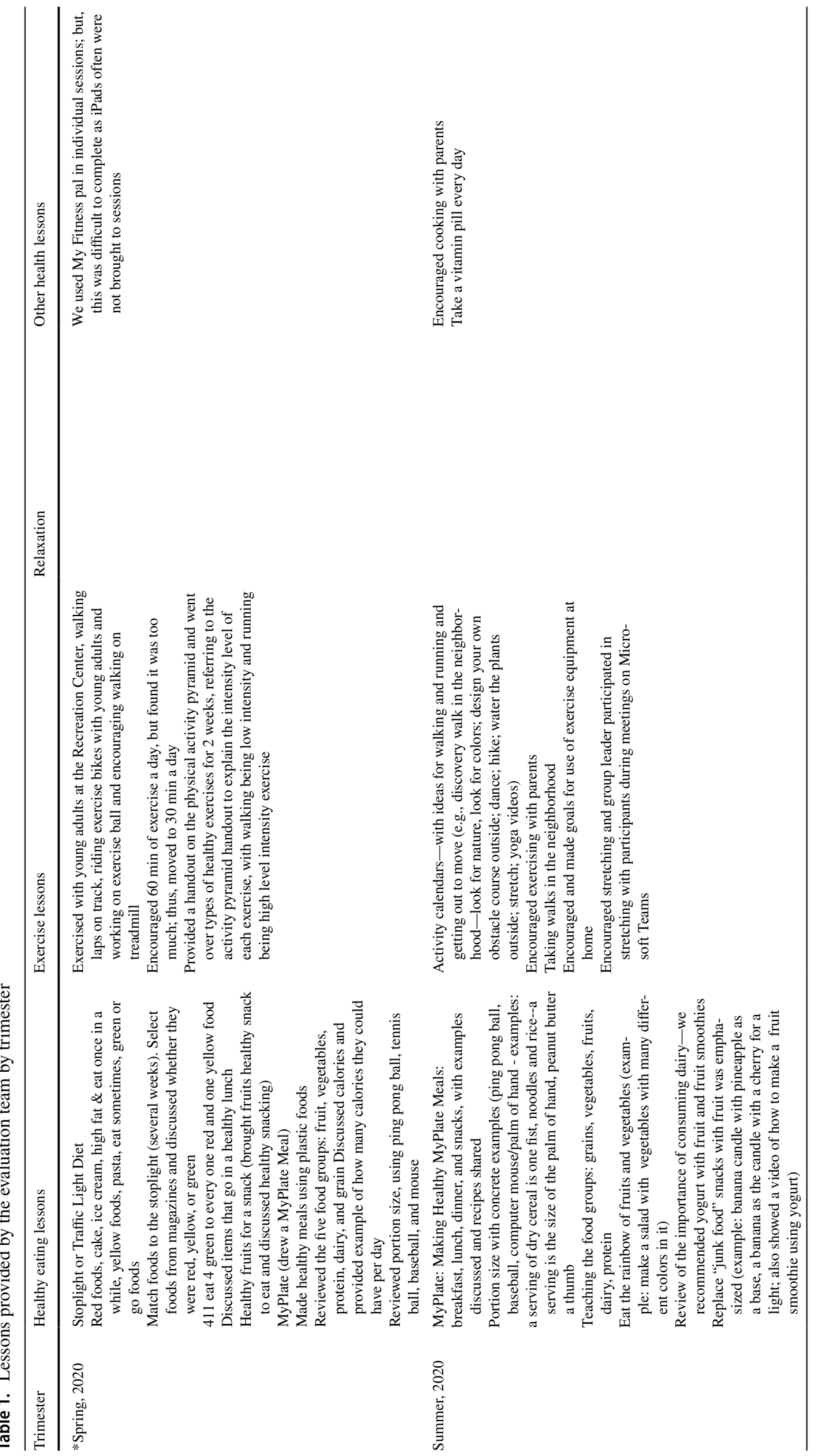




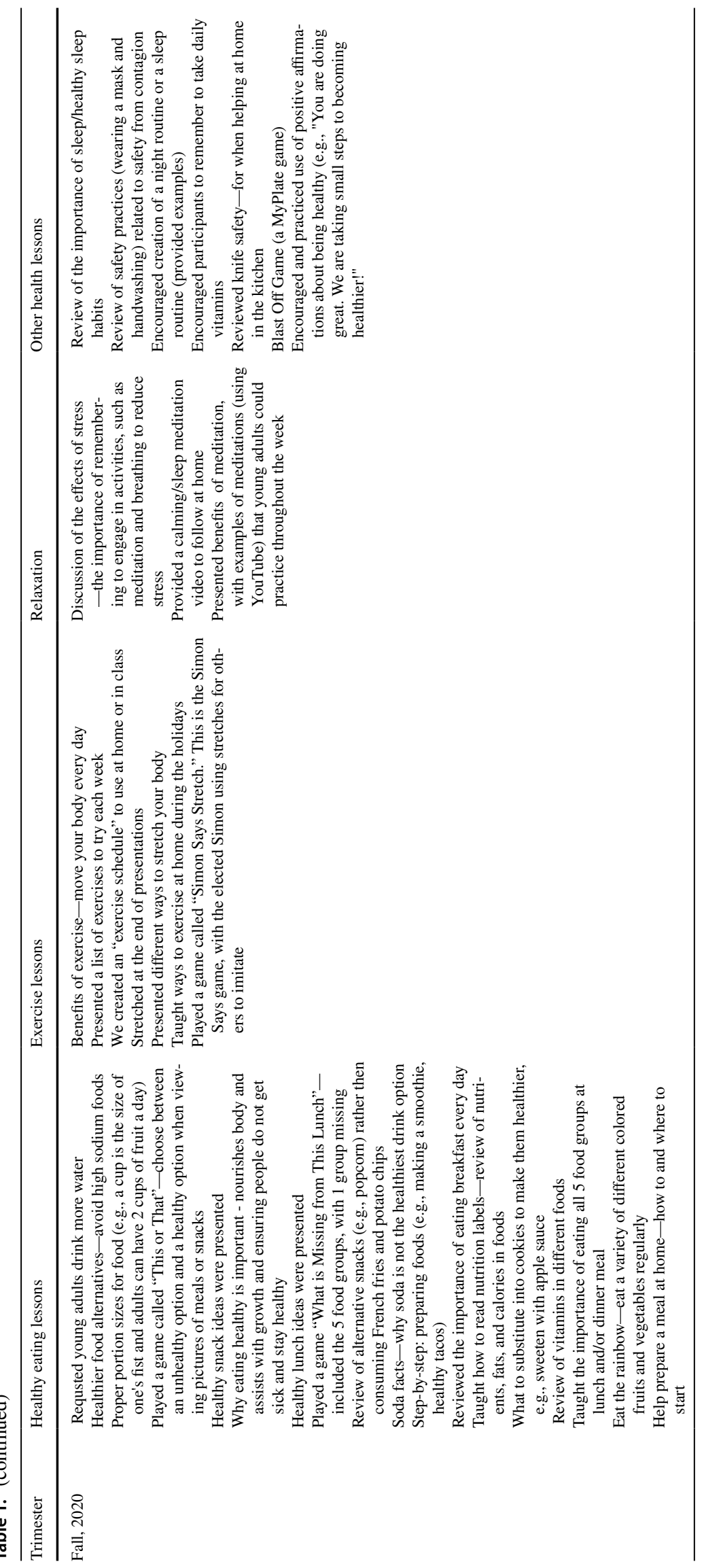




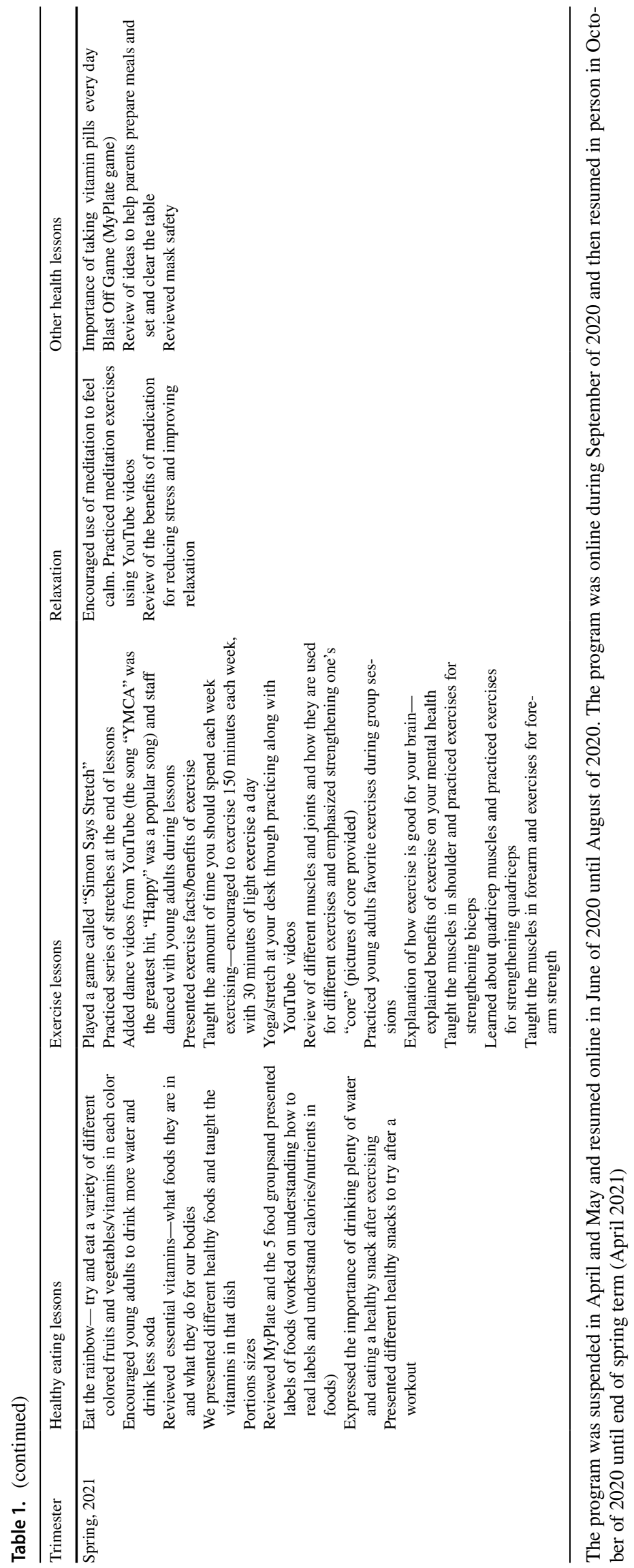


The evaluation team developed lessons, featuring visual content, and presented the lessons on PowerPoint ${ }^{\circledR}$ slides at the beginning of the week to small groups of four to six young adults. The staff working with participants reviewed the lessons (PowerPoint slides) with young adults two other times during the week. The slides featured information about MyPlate and healthy meals and snacks, information about food groups, portion size, healthy snacks, calories in foods, reading nutrition labels, and cooking healthy meals (see Table 4). Young adults were encouraged to cook meals with parents, and videos of simple recipes (e.g., smoothies, avocado dip) were reviewed. One member of the evaluation team created a game called "This or That." This game involved reviewing a slide with a photo of an unhealthy food and a photo of a healthy food. Participants identified the healthier food. Most of the slides were developed featuring a "junk food" and a healthy alternative. In terms of exercise, participants reviewed the benefits of exercise and stretching, how often to exercise, types of exercise, and muscles involved in exercise. They often practiced exercises with group leaders who were following YouTube videos of trainers or models leading "chair exercises" and/or stretching (see Table 4).

Lessons featured group-based MI (Miller \& Rollnick, 2002). Group leaders reviewed goal setting and shared their own healthy eating goals. They discussed setting small goals and taking small steps toward more positive eating and exercise habits. Group leaders encouraged participants to develop their healthy eating and exercise goals. The group leader assisted each participant in selecting two goals, which typically were a healthy eating and a healthy exercise goal. The leader recorded participants' goals. These were then added to the PowerPoint presentation, which was reviewed two other times during the week. Praise for effort and praise for selecting goals was included on slides in weekly lessons. There were three breaks from goal setting (typically lasting 2-3 weeks) during the intervention.

Weekly "check-in" meetings with administrators and implementation logs were developed to receive staff input. The evaluation team contacted parents/caregivers through newsletters, sending home recipes, and through surveys sent via email or google docs. Goals for participants were shared with the staff in order for the staff to be able to share goals with parents. Surveys were forwarded to parents, so that parents could evaluate the program. Height and weight were recorded every 2 to 3 months. Participants were weighed without their shoes. Group interviews with young adults were used to examine their perceptions of the program. The staff completed implementation logs on a biweekly basis.

\section{Measures}

Goal Attainment Sheet Group leaders recorded young adults' goals; date goals were developed, and whether they attained the goals ("yes" or "no") on individual goal sheets for each young adult.

Assessment of Height and Weight Additionally, the team assessed participants' height using a stadiometer and weight using a Weight Watchers Scale ${ }^{\circledR}$.

Implementation Logs Implementation logs had a column for which activities were implemented and areas for improving lessons. Questions on implementation logs included opinions about the programming, perceptions of the implementation of lessons during the week, changes made by the staff or young adults, and ideas for improving programming. The staff completed implementation logs in the summer and fall of 2020 and spring of 2021. The evaluation team met regularly to discuss the implementation of the program and improve lessons for the program.

Parent Surveys Parents/caregivers responded to "yes/no" and open-ended questions to provide information about whether they had learned of eating and exercise goals selected by their child. They reported whether young adults were eating more healthy foods and engaging in higher levels of exercise.

Group Interviews with Young Adults Some of the participants (12 of the 17 young adults) also volunteered to complete group interviews to examine changes in their knowledge about healthy eating and exercise, whether they drank more water and less soda, and to provide general knowledge about what they learned from participating in programming. Specifically, three groups with four participants in each group were conducted in the spring of 2021. Young adults answered several questions to assess their learning from the program, what they learned about healthy eating and exercise, and if they drank more water and/or less soda. Group interviews lasted about $15 \mathrm{~min}$.

\section{Data Analyses}

A single-subject design was used to examine goals for young adults and weight change. Descriptive statistics and qualitative methods were used to analyze data from parent surveys and implementation logs. Qualitative analyses were used to determine key information in young adults' responses for group interviews. 


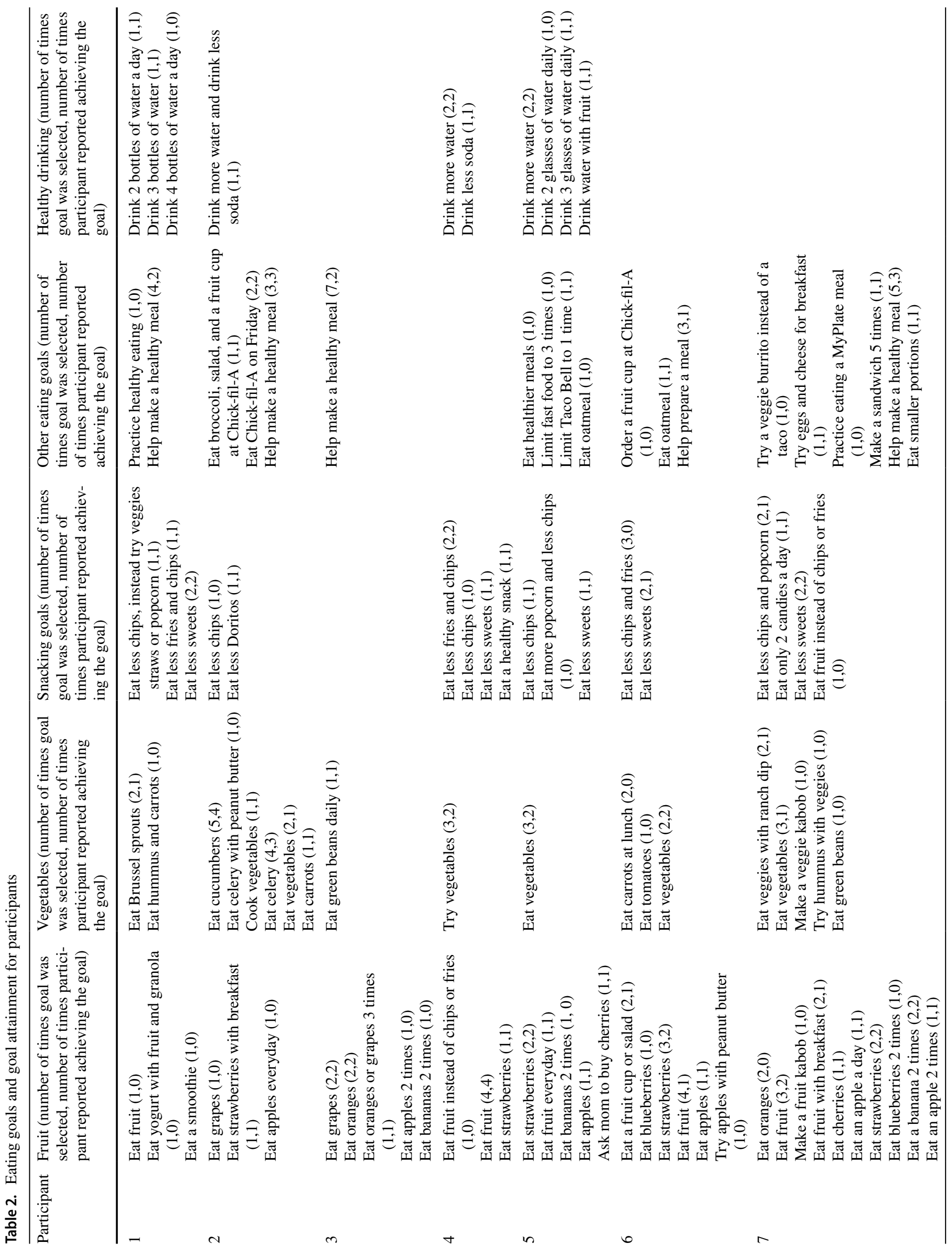




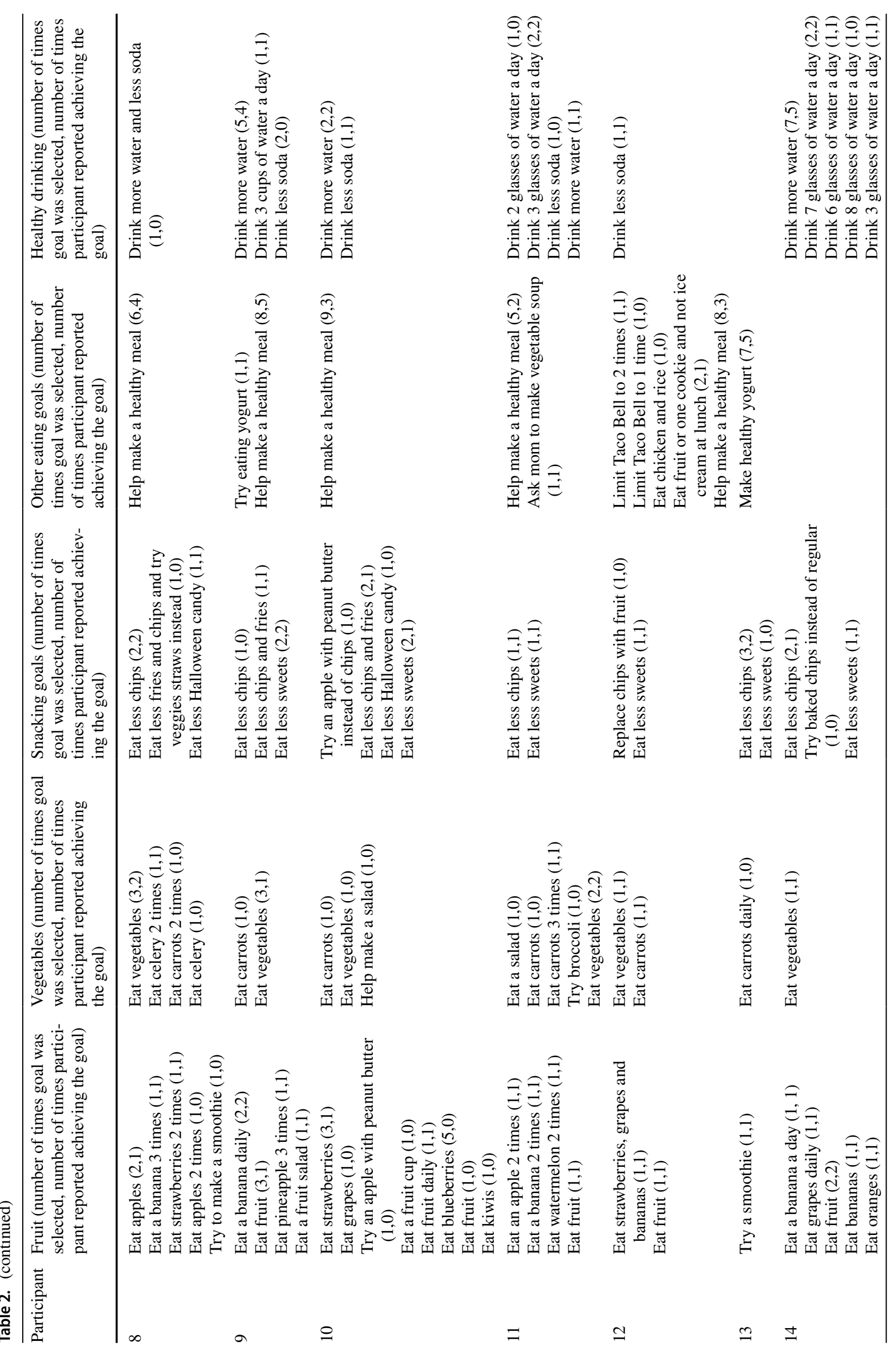




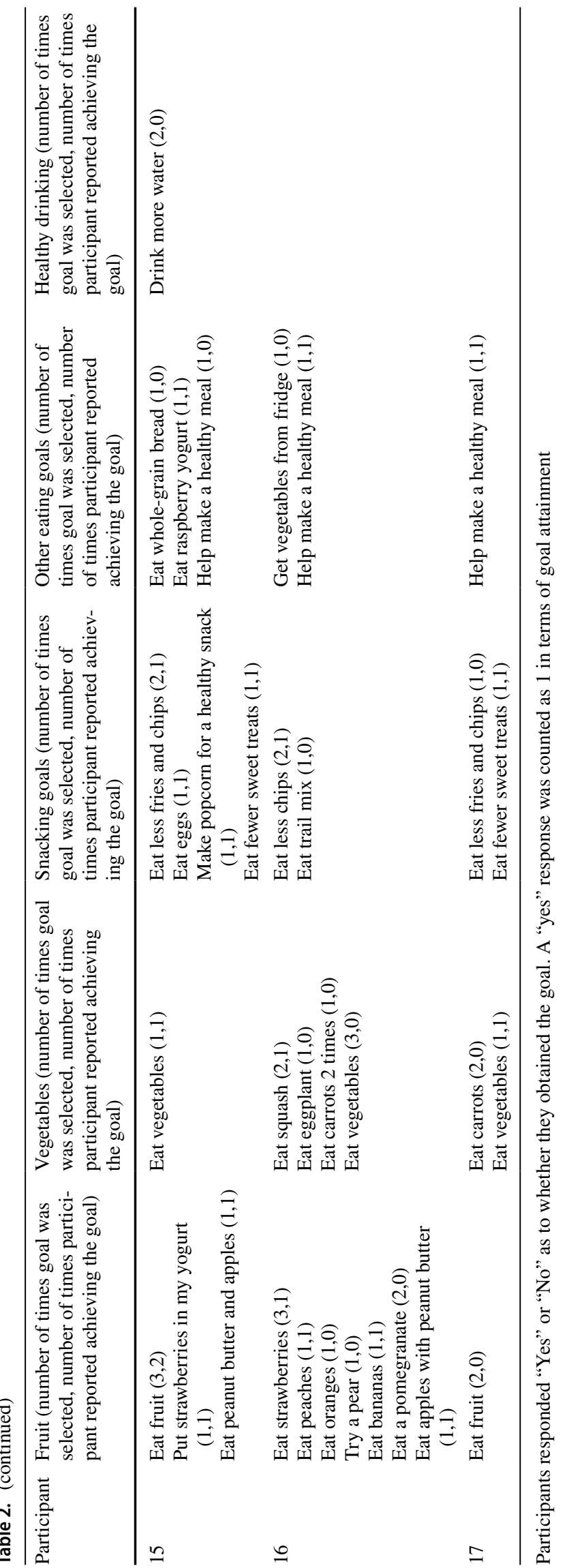

\section{Results}

\section{Eating and Exercise Goals}

Tables 2 and 3 summarize eating and exercise goals selected by participants. The information in parentheses is the number of times the participant selected the goal and the number of times that the participant reported achieving the goal. Goals for eating fruit were popular (see Table 2). Other popular eating goals included trying to eat less junk food and activities such as helping with grocery shopping. Another area of interest was drinking water rather than soda. Participants were encouraged to participate in meal preparation and goals could be to help with making food or setting or clearing the table (see Table 3). Participants often selected walking as a goal. Other exercise goals included playing soccer, riding a bike, dancing to music, stretching, hiking, and swimming (see Table 3). Health lessons also featured healthy sleep routines, so some selected goals centered on those lessons. Goals did at times mirror health programming, which was encouraging.

Table 4 presents the number of goals set and achieved over the course of the program. Participants were more successful in achieving exercise goals and goals for drinking more water compared to eating goals.

\section{Weight Change}

Assessment of weight is presented in Table 5. Several participants lost weight, with two moving from obese to overweight, and for most, weight remained largely unchanged. A few gained some weight, but did not change, in terms of BMI category. One participant gained weight, moving to a higher BMI category (parent-caregiver report indicated weight gain was, in part, related to staying at home during the pandemic).

\section{Implementation Logs}

The staff completed 35 implementation logs. Perceptions of the health programming were favorable. Suggestions included adding videos (e.g., for cooking and exercise demonstrations), adding more recipes for healthy eating, and providing rewards to participants for reaching goals. It was suggested that our team bring in fruits and vegetables for participants to sample during groups. However, during COVID-19, this was not approved by the program. Similarly, the staff wanted to use measuring cups and food to learn portion sizes, but this was not possible during the pandemic. The staff reported that learning through games, such as healthy food bingo, was well liked by young adults. The staff felt lessons focusing on identifying and reducing 
Table 3. Exercise goals and goal attainment for participants

\begin{tabular}{|c|c|c|c|c|}
\hline Participant & $\begin{array}{l}\text { Exercise (number of times goal } \\
\text { was selected, number of times } \\
\text { participant reported achieving } \\
\text { the goal) }\end{array}$ & $\begin{array}{l}\text { Walk (number of times goal } \\
\text { was selected, number of times } \\
\text { participant reported achieving } \\
\text { the goal) }\end{array}$ & $\begin{array}{l}\text { Stretching (number of times } \\
\text { goal was selected, number } \\
\text { of times participant reported } \\
\text { achieving the goal) }\end{array}$ & $\begin{array}{l}\text { Other healthy lifestyle goals } \\
\text { (number of times goal was } \\
\text { selected, number of times } \\
\text { participant reported achieving } \\
\text { the goal) }\end{array}$ \\
\hline 1 & $\begin{array}{l}\text { Ride a bike }(9,5) \\
\text { Swim }(1,1) \\
\text { Try pushups }(1,1) \\
\text { Try sit-ups }(1,1) \\
\text { Workout this week }(2,1)\end{array}$ & Walk $(8,5)$ & $\begin{array}{l}\text { Do yoga }(1,1) \\
\text { Full body stretches daily }(1,1) \\
\text { Stretch after walking }(1,1)\end{array}$ & $\begin{array}{l}\text { Get } 8 \text { h of sleep }(1,0) \\
\text { Practice mindfulness }(1,0) \\
\text { Set the table }(1,0) \\
\text { Help with grocery shopping } \\
\quad(1,1)\end{array}$ \\
\hline 2 & $\begin{array}{l}\text { Exercise at rec center }(4,4) \\
\text { Ride a bike }(2,2) \\
\text { Use treadmill }(3,2) \\
\text { Jump rope }(5,4) \\
\text { Play basketball } 3 \text { times for } 20 \\
\quad \text { min }(1,1) \\
\text { Play soccer } 2 \text { times }(1,1)\end{array}$ & Walk $(11,7)$ & $\begin{array}{l}\text { Stretch } 3 \text { times this week }(1,1) \\
\text { Stretch daily }(3,3)\end{array}$ & $\begin{array}{l}\text { Read a book before bed every } \\
\text { night }(1,1)\end{array}$ \\
\hline 3 & $\begin{array}{l}\text { Swim } 2 \text { times }(1,0) \\
\text { Play soccer } 3(1,0)\end{array}$ & Walk $(6,4)$ & & $\begin{array}{l}\text { Get outside }(3,2) \\
\text { Prepare and be ready for } \\
\text { Healthy Bearcats this week } \\
(1,1)\end{array}$ \\
\hline 4 & $\begin{array}{l}\text { Exercise at rec center }(6,6) \\
\text { Swim }(4,3) \\
\text { Exercise }(1,1)\end{array}$ & Walk $(12,8)$ & Stretch $(2,2)$ & $\begin{array}{l}\text { Help around the house }(1,1) \\
\text { Set the table }(1,1)\end{array}$ \\
\hline 5 & $\begin{array}{l}\text { Do } 5 \text { jumping jacks a day }(1,1) \\
\text { Swim }(7,6) \\
\text { Play soccer } 3 \text { times }(1,1) \\
\text { Punch a punching bag }(2,2) \\
\text { Try boxing } 2 \text { times }(1,1) \\
\text { Exercise }(1,1)\end{array}$ & Walk $(2,3)$ & $\begin{array}{l}\text { Stretch }(2,0) \\
\text { Stretch } 3(1,1)\end{array}$ & $\begin{array}{l}\text { Sleep } 7-8 \text { hours a night }(1,0) \\
\text { Read a book before bed }(1,0) \\
\text { Dance } 3 \text { times }(1,1) \\
\text { Help set the table }(5,5) \\
\text { Do the dishes }(1,1)\end{array}$ \\
\hline 6 & $\begin{array}{l}\text { Try squats at the gym }(2,1) \\
\text { Ride a bike }(1,1) \\
\text { Exercise more }(3,1)\end{array}$ & Walk $(8,4)$ & $\begin{array}{l}\text { Take a yoga class }(1,1) \\
\text { Do stretches using a ball }(1,0) \\
\text { Stretch } 5 \text { times }(1,0) \\
\text { Stretch } 4 \text { times }(1,0)\end{array}$ & $\begin{array}{l}\text { Help around the house }(2,1) \\
\text { Do the dishes }(1,0)\end{array}$ \\
\hline 7 & $\begin{array}{l}\text { Exercise at rec center }(4,4) \\
\text { Play basketball }(1,1) \\
\text { Try a workout with a partner } \\
\quad(1,1)\end{array}$ & Walk $(23,17)$ & & $\begin{array}{l}\text { Play games on Wii Fit }(2,1) \\
\text { Try bowling }(1,0) \\
\text { Turn off iPad } 1 \mathrm{~h} \text { before bed } \\
\quad(1,0)\end{array}$ \\
\hline 8 & $\begin{array}{l}\text { Try squats }(2,2) \\
\text { Play soccer } 3 \text { times }(1,1) \\
\text { Ride a bike }(5,4) \\
\text { Try a workout }(1,1)\end{array}$ & Walk $(7,6)$ & $\begin{array}{l}\text { Stretch } 2 \text { times }(1,0) \\
\text { Stretch } 3 \text { times for } 20 \min (1,1)\end{array}$ & Help set the table $(1,0)$ \\
\hline 9 & $\begin{array}{l}\text { Ride a bike }(4,2) \\
\text { Exercise }(1,0) \\
\text { Try pushups }(1,0) \\
\text { Try wall sits }(1,0) \\
\text { Try an indoor exercise or walk } \\
\text { outside }(1,1)\end{array}$ & Walk $(17,8)$ & & $\begin{array}{l}\text { Go to bed every night by } 10 \mathrm{pm} \\
(1,0) \\
\text { Eat healthier }(1,1) \\
\text { Help set the table }(1,1)\end{array}$ \\
\hline 10 & $\begin{array}{l}\text { Jog } 1 / 2 \text { lap }(3,1) \\
\text { Do } 10 \text { jumping jacks }(2,0) \\
\text { Bike } 3 \text { times for } 20 \text { minutes } \\
\quad(1,1) \\
\text { Exercise }(1,1) \\
\text { Do } 25 \text { jumping jacks } 5 \text { times } \\
\quad(1,0) \\
\text { Try a YouTube workout }(1,0)\end{array}$ & Walk $(11,9)$ & Try yoga $(1,1)$ & $\begin{array}{l}\text { Try dancing }(3,2) \\
\text { Review healthy food }(1,0) \\
\text { Ask for vitamins }(1,0)\end{array}$ \\
\hline 11 & $\begin{array}{l}\text { Swim } 2 \text { times }(1,0) \\
\text { Try running on treadmill }(1,0) \\
\text { Play basketball }(1,0) \\
\text { Exercise outside }(1,1)\end{array}$ & Walk $(9,6)$ & Stretch 3 times $(1,1)$ & $\begin{array}{l}\text { Turn off iPad before bed }(1,1) \\
\text { Help set the table }(2,2)\end{array}$ \\
\hline
\end{tabular}


Table 3. (continued)

\begin{tabular}{|c|c|c|c|c|}
\hline Participant & $\begin{array}{l}\text { Exercise (number of times goal } \\
\text { was selected, number of times } \\
\text { participant reported achieving } \\
\text { the goal) }\end{array}$ & $\begin{array}{l}\text { Walk (number of times goal } \\
\text { was selected, number of times } \\
\text { participant reported achieving } \\
\text { the goal) }\end{array}$ & $\begin{array}{l}\text { Stretching (number of times } \\
\text { goal was selected, number } \\
\text { of times participant reported } \\
\text { achieving the goal) }\end{array}$ & $\begin{array}{l}\text { Other healthy lifestyle goals } \\
\text { (number of times goal was } \\
\text { selected, number of times } \\
\text { participant reported achieving } \\
\text { the goal) }\end{array}$ \\
\hline 12 & $\begin{array}{l}\text { Lift weights }(1,1) \\
\text { Play basketball }(1,1) \\
\text { Play soccer every day }(1,1) \\
\text { Play football }(1,0) \\
\text { Go for a run or bike ride }(1,1) \\
\text { Play golf with Dad }(1,0)\end{array}$ & Walk $(5,4)$ & Pull legs to chest stretch $(1,0)$ & \\
\hline 13 & Ride bike everyday $(1,0)$ & Walk $(4,4)$ & Stretch 5 times $(1,0)$ & $\begin{array}{l}\text { Try a dance to my favorite song } \\
(1,1) \\
\text { Read a book before bed }(1,0) \\
\text { Help around the house }(1,1) \\
\text { Help set the table }(1,1)\end{array}$ \\
\hline 14) & $\begin{array}{l}10 \text { jumping jacks }(1,1) \\
\text { Try a new exercise }(4,1) \\
\text { Work on the exercise ball }(1,1)\end{array}$ & Walk $(14,11)$ & & Help set the table $(1,1)$ \\
\hline 15) & Do jumping jacks 2 times $(1,1)$ & Walk $(10,5)$ & Do stretches $(3,2)$ & $\begin{array}{l}\text { Help set the table }(4,3) \\
\text { Clear the table }(2,1)\end{array}$ \\
\hline 16) & $\begin{array}{l}\text { Exercise at the rec center }(2,2) \\
\text { Swim }(5,3) \\
\text { Run }(2,2) \\
\text { Hike }(6,4) \\
\text { Play soccer two times }(1,1)\end{array}$ & Walk $(4,1)$ & Stretch 4 times $(1,1)$ & $\begin{array}{l}\text { Help put glasses and plates on } \\
\text { the table }(1,0)\end{array}$ \\
\hline 17 & $\begin{array}{l}\text { Exercise }(5,3) \\
\text { Try a new exercise }(1,0)\end{array}$ & Walk $(5,2)$ & & \\
\hline
\end{tabular}

Participants responded "Yes" or "No" as to whether they obtained the goal. A "yes" response was counted as 1 in terms of goal attainment

intake of junk food and fast food were very helpful for young adults. For example, the staff reported that discussing how French fries were not a healthy lunch option, compared to selecting a fruit cup or a salad was a useful idea. Similarly, having yogurt as a snack as opposed to potato chips or sweets was a good health lesson. Another staff member reported that showing what options were healthier in our slides was helpful, and requested "more examples of healthy foods available." The staff asked for different lessons for high functioning and lower functioning young adults in the slides, as a way to improve the lessons. The staff records indicated that young adults were selecting more fruits and walking more. However, only one young adult was observed to be eating more vegetables.

\section{Parent Surveys}

Six of sixteen parents ( 5 females, 1 male) completed email surveys. All reported the program was helpful for their young adult. For instance, a mother of a female in her mid-20s reported, "she was eating healthier and exercising more." Being in the program helped her daughter in "drinking more water, eating more fruits and vegetables." This mother reported her daughter's increased awareness of healthier food options. One mother reported her daughter was, "making slow, steady progress with better diet and exercise decisions and habits." Another mother reported that her son was discussing ways to help at home and was involved with her in making healthier meals. A mother of a male remarked that although COVID-19 varied what was "in the fridge," her son was still eating a variety of fruits and healthier snacks." Mainly, he was eating a variety of fruits, which was an improvement over his previous snack choices. One father reported that participating in programming helped his daughter maintain her weight during the pandemic.

All parents reported that exercise goals were positive for young adults. Parents reported improvements in increasing engagement in exercise, typically activities involving light exercise, especially walking. For example, one mother said, "____ (name of young adult) tells me every day she needs to walk more. This week we have been at____ (vacation spot). She has walked over a mile every day. I'm so proud of her." Another mother reported her son was trying to walk more and another was riding the exercise bike at home.

Parents did report increases in healthy eating, which included eating yogurt, eating more fruit (as a healthy snack), and eating smaller portion sizes. One mother 
reported her child was drinking less soda and more water, and this was a young adult who really needed to make this change. Young adults were helping out more at home and cooking with parents, as they followed their program goals. Parents/caregivers and the participants reported enjoying working together. One mother stated, “____ (name) has increased his interest in cooking with me, which I would attribute to (program name: Eat and Exercise to Win Program). The Eat and Exercise to Win Program has been a good reminder for me to reinforce with (name of participant) on healthy food choices when we cook together." Another participant also began cooking with his father, making scrambled eggs and omelets. He was exercising more with his parents as well.

\section{Group Interviews}

Group one consisted of two females and two males. Participants were asked, "What did you learn in Healthy Bearcats this spring?" Three of the participants spoke about eating more fruits. One female reported "MyPlate" when asked what she learned. One male reported learning about "exercising." A probing question was asked by the interviewer, "Did you help at home more, because of being in our program?" Two of the participants reported they helped out at home, one did not answer, and one provided an unrelated answer. Next, participants reported what they learned about healthy eating. Three of the four participants reported that they were eating healthier due to program participation. One female answered, "Water and eating fruit." The other female said she was already eating healthy before coming to our program. One male reported he was eating apples and popcorn. The other male said he was eating more vegetables and eating bananas. The third question focused on what was learned about exercise. In response, participants demonstrated an exercise they learned. The females demonstrated leg kicks. One male demonstrated reaching his hands to the sky (one of the stretching exercises), while the other said, "walking." Participants reported whether they were drinking more water. One female and two males said they were drinking more water. The other female said she was already drinking more water before participating in the program. One male also said he was drinking less soda.

Group 2 was comprised of one female and four males. Different answers were provided for what had been learned, but all participants reported improved health behaviors. Three of the four participants in Group 2 answered the second question, reporting what they had learned about healthy eating. One male said he learned, "how to eat healthy and to drink more water." One male reported he learned that, "walking is good for you." One female stated that she learned "walking on the treadmill is 
Table 5. Weight change for participants

\begin{tabular}{|c|c|c|c|c|c|c|}
\hline Gender, height & $\begin{array}{l}\text { Weighttime 1, February } \\
2020\end{array}$ & $\begin{array}{l}\text { Weight time } \\
2, \text { September } \\
2020\end{array}$ & $\begin{array}{l}\text { Weight time } \\
3 \text {, December } \\
2020\end{array}$ & $\begin{array}{l}\text { Weight time } 4, \\
\text { February } 2021\end{array}$ & $\begin{array}{l}\text { Weight time } \\
5 \text {, April } 2021\end{array}$ & $\begin{array}{l}\text { BMI category and } \\
\text { category change, if } \\
\text { applicable for the case }\end{array}$ \\
\hline $\begin{array}{l}\text { Female, } 158 \mathrm{~cm} \\
\text { About } 5^{\prime} 2^{\prime \prime}\end{array}$ & $171.2 \mathrm{lbs}$ & $162.6 \mathrm{lbs}$ & $155 \mathrm{lbs}$ & $148.6 \mathrm{lbs}$ & $150 \mathrm{lbs}$ & $\begin{array}{l}\text { Moved from obese to } \\
\text { overweight category }\end{array}$ \\
\hline $\begin{array}{l}\text { Female, } 167-170 \mathrm{~cm} \text {, } \\
\text { about } 5^{\prime} 6^{\prime \prime}\end{array}$ & $177.4 \mathrm{lbs}$ & $176.7 \mathrm{lbs}$ & & $177 \mathrm{lbs}$ & $174.4 \mathrm{lbs}$ & Overweight \\
\hline $\begin{array}{l}\text { Female, } 176.8 \mathrm{~cm}, \\
\text { about } 5^{\prime} 8^{\prime \prime}\end{array}$ & & & & $304 \mathrm{lbs}$ & $303.8 \mathrm{lbs}$ & Obese \\
\hline $\begin{array}{l}\text { Female, } 152 \mathrm{~cm} \text {, about } \\
5^{\prime \prime}\end{array}$ & $167.2 \mathrm{lbs}$ & $171 \mathrm{lbs}$ & & $152.5 \mathrm{lbs}$ & $151.2 \mathrm{lbs}$ & $\begin{array}{l}\text { Moved from obese to } \\
\text { overweight category }\end{array}$ \\
\hline $\begin{array}{l}\text { Female, } 172 \mathrm{~cm} \text {, about } \\
5^{\prime} 6^{\prime \prime}\end{array}$ & & $123.4 \mathrm{lbs}$ & $128.4 \mathrm{lbs}$ & $126.6 \mathrm{lbs}$ & $128 \mathrm{lbs}$ & Normal \\
\hline Female, $158 \mathrm{~cm}, 5^{\prime} 2^{\prime \prime}$ & $215.6 \mathrm{lbs}$ & $221.4 \mathrm{lbs}$ & & $242.2 \mathrm{lbs}$ & $228.6 \mathrm{lbs}$ & Obese \\
\hline $\begin{array}{l}\text { Female, } 157-159 \mathrm{~cm} \text {, } \\
\text { estimated almost } 5^{\prime} 2^{\prime \prime}\end{array}$ & $123.6 \mathrm{lbs}$ & $129.2 \mathrm{lbs}$ & $130.6 \mathrm{lbs}$ & $127.4 \mathrm{lbs}$ & $129.2 \mathrm{lbs}$ & Normal \\
\hline $\begin{array}{l}\text { Male, } 168.4 \mathrm{~cm} \text {, about } \\
5^{\prime} 5^{\prime \prime}\end{array}$ & $207.4 \mathrm{lbs}$ & $190.6 \mathrm{lbs}$ & & $190.4 \mathrm{lbs}$ & $191 \mathrm{lbs}$ & Obese \\
\hline $\begin{array}{l}\text { Male, } 173 \mathrm{~cm} \text {, about } \\
5^{\prime} 6^{1 / 2^{\prime \prime}}\end{array}$ & & $127.6 \mathrm{lbs}$ & $135.4 \mathrm{lbs}$ & $132.2 \mathrm{lbs}$ & $130.2 \mathrm{lbs}$ & Normal \\
\hline $\begin{array}{l}\text { Male, } 187.5 \mathrm{~cm} \text {, about } \\
6^{\prime} 1^{\prime \prime}\end{array}$ & $211.2 \mathrm{lbs}$ & $224.6 \mathrm{lbs}$ & $225.4 \mathrm{lbs}$ & $238.6 \mathrm{lbs}$ & $228.8 \mathrm{lbs}$ & $\begin{array}{l}\text { Moved from overweight } \\
\text { to obese category }\end{array}$ \\
\hline Male & Unable to determine & & & & & \\
\hline $\begin{array}{l}\text { Male, } 162.5 \mathrm{~cm} \text {, about } \\
5^{\prime} 3^{\prime \prime}\end{array}$ & $210.8 \mathrm{lbs}$ & $201.8 \mathrm{lbs}$ & & $203.2 \mathrm{lbs}$ & $200.4 \mathrm{lbs}$ & Obese \\
\hline $\begin{array}{l}\text { Male, } 182 \text { or } 183 \mathrm{~cm} \text {, } \\
\text { about } 6^{\prime}\end{array}$ & & & & $196.8 \mathrm{lbs}$ & $200.4 \mathrm{lbs}$ & Overweight \\
\hline $\begin{array}{l}\text { Male, } 172 \mathrm{~cm} \text {, about } \\
5^{\prime} 6^{\prime \prime}\end{array}$ & & $182 \mathrm{lbs}$ & & $184.6 \mathrm{lbs}$ & $184.4 \mathrm{lbs}$ & Overweight \\
\hline $\begin{array}{l}\text { Male, } 188 \mathrm{~cm} \text {, about } \\
62^{\prime \prime}\end{array}$ & & & & $197.6 \mathrm{lbs}$ & $202 \mathrm{lbs}$ & $\begin{array}{l}\text { Normal to overweight } \\
\text { category }\end{array}$ \\
\hline $\begin{array}{l}\text { Male, } 171.5 \mathrm{~cm} \text {, about } \\
5^{\prime} 6^{\prime \prime}\end{array}$ & $141 \mathrm{lbs}$ & $128 \mathrm{lbs}$ & & $131 \mathrm{lbs}$ & $133 \mathrm{lbs}$ & Normal \\
\hline $\begin{array}{l}\text { Male, } 174 \mathrm{~cm} \text {, about } \\
5^{\prime} 7^{\prime \prime}\end{array}$ & $135.2 \mathrm{lbs}$ & & & $131 \mathrm{lbs}$ & $137.6 \mathrm{lbs}$ & Normal \\
\hline
\end{tabular}

Unable to determine one male's weight as he did not participate in being weighed

good for you." The last male chose not to respond. Finally, participants were asked what they learned about exercise during the program. All participants demonstrated the stretches they learned. Almost all participants stated that a stretch they learned was to "reach up to the sky" (three males). One of the males in the group said he learned "arm pull-downs." One male said he learned to "exercise for 30 minutes a day and wrist curls." One male said he learned nothing about exercise, but staff stated this is because it is hard for him to exercise without having a partner. One female reported that she "learned to walk on the track and stretch arms." Three of the participants reported drinking more water, while one male, who really liked water, said his intake was about the same. Two of the participants drank less soda (one male and one female) and the other two participants (both of whom were male) reported that their soda consumption was about the same.

Group 3 had two males and two females. Each participant had a different response for what he or she had learned from participating in the program. One male said he "learned to drink more water." One female said she had "learned about healthy eating." One female said she "learned to walk for exercise." The other male indicated he had "learned how to be healthy." Next, participants responded to a question about what they learned about healthy eating. Two of the individuals said they learned to "drink more water" (two females). One male said he learned "how to make healthy baked beans and also that basketball is good for you." One male stated that he "learned about healthy food options." The third question focused on what was learned about exercise. All 
participants had different responses, but they all demonstrated the stretches they learned. One male responded that he learned "exercise makes you healthier and he learned to stretches to do at home." One female said she learned that "swimming is good for you and stretching is good for you." One female stated "I don't like exercise but it is good for you and learned to stretch arms over chest." One male said he learned "exercise is good for you and learned to stretch arms up to the sky." Two of the individuals said they learned to "drink more water" (two females).

\section{Discussion}

Results provided support for use of group-based MI for young adults with ASD and IDs attending healthy eating and exercising programming. Thus, similar to other research on group-based MI with young adults with chronic illnesses (Schaefer \& Kavookjian, 2017), this technique appeared promising for young adults with ASD and IDs. The staff reported that participants benefitted from being encouraged and praised for moving forward, a key component of this approach (Miller \& Rollnick, 2002). Young adults were able to select goals and report on goal attainment. The program was implemented during COVID-19, and changed to provide lessons using PowerPoint slides that could be delivered by the program staff throughout the week. Lessons began by featuring the Traffic Light Diet (Epstein, 2005), but were changed after receiving feedback. Hence, similar to Weems et al. (2017), we found there may be difficulties understanding the Traffic Light Diet. However, the difficulty we encountered centered on the color of foods, not the frequency of eating foods, which was cited by Weems et al. (2017). Orienting programming toward presenting MyPlate meals, and presenting information about food groups using MyPlate examples, and creating visually oriented lessons, with examples of what to eat for meals and snacks, was the next phase in educational sessions. In some ways, programming became similar to some information presented in the TAKE 5 Program (Melville et al., 2011). However, we cannot determine if this program was as successful as the TAKE 5 Program (Harris et al., 2017), as there was not a control group and the experimental control was not at the level needed for trials of the program. The staff reported that the visual displays (pictures, videos) were important teaching tools, and this is consistent with recommendations for programming (Grumstrup \& Demchak, 2017).

There were other successful facets of the program. For example, visual displays were provided to learn about portion size. For example, a selection of protein was typically the size of a "checkbook." A serving of pasta would fit in the palm of one's hand. Young adults exercised with group leaders at the campus recreation center prior to the pandemic. During the pandemic, when lessons were delivered on Microsoft Teams ${ }^{\circledR}$, the young adults did participate in stretching exercises with the group leader, observing her stretches and then imitating them. Similarly, when they returned to the classroom, participants continued stretching and worked out in their chairs, following videos featuring chair exercises. Walking was a favorite exercise before and during the pandemic.

Similar to other research with adults (Abughosh et al., 2019), young adults with ASD and IDs benefitted from the positive, group-based MI approach. They were selecting goals and this resulted in them eating more healthy foods, trying new vegetables, and helping with meal preparation. The goals they selected tended to focus primarily on eating more fruits or drinking water rather than soda, but they were able to select goals for eating more vegetables (chiefly broccoli, carrots, and corn). With encouragement, some young adults were able to make goals to reduce unhealthy snacking and eat healthy snacks, typically by having fruit, yogurt and fruit, or vegetables with dip or hummus. Participants were able to drink more water, especially when flavored with fruit, and exchange water for soda. Participants responded well to praise and encouragement, which were incorporated in daily lessons. MI was discussed with parents/caregivers who also believed this approach was a good one to use.

Two of the females lost weight, moving from the obese to the overweight category. This is important, as many young adults with ASD and IDs need to lose weight (Hsieh et al., 2014; Li et al., 2020; Zheng et al., 2017). One male did gain weight; this could have been due to remaining home more during COVID-19, which also could have negatively impacted weight loss for other participants who were at home during the pandemic. Many maintained their weight, remaining in the same BMI category. It may be that program participation reduced weight gain during the pandemic, but without a comparison or control group, it is not possible to assess this. Participants were also less able to exercise during the pandemic; however, with encouragement, they were walking and using treadmills as well as exercise bikes at home. Similar to a report by Ptomey et al. (2018), the Traffic Light Diet (Epstein, 2005) needed to be discontinued. A staff and a parent reported that the colors in the traffic light could be confused with food colors, and this could be bewildering for participants. Also, a traffic light was used in a positive behavior management system at the program, and having two traffic lights was confusing.

The program was modified to emphasize MyPlate with the MyPlate system for developing healthy meals and snacks. Portion size was another area of emphasis, using concrete examples to teach portions-such as a serving of protein is the size of a checkbook. The young adults responded well 
to examples, especially when presented through games. Repeating lessons, by showing PowerPoint slides two more times over the course of the week, helped solidify learning. The group-based MI proved successful, with young adults responding positively to praise and positive messaging. The young adults were able to select their own goals, primarily selecting increasing walking and eating different types of fruits as favorite goals. As indicated in Table 4, participants selected a variety of goals, including trying new foods, such as vegetables. Additionally, they were excited about helping with meal preparation and making things like smoothies and tacos. It may be possible to combine healthy eating and exercise programming with life skills training in the future. About one-third of the participants lost some weight, and program staff and parents who responded to surveys reported success for the program in changing knowledge and behaviors. This program, which was modified to become more similar to the TAKE 5 Program (Harris 2017; Melville et al., 2011), had some success in improving the weight and eating and exercise behaviors of participants.

Parents reported satisfaction with the program. On the other hand, only about a third of the parents returned surveys despite several reminders. Parents who responded indicated they were aware of goals and felt that their child's eating behaviors were "healthier." They noted increases in fruit consumption. They reported improvements in exercise. One parent reported that the program was successful in attenuating weight gain and unhealthy eating during the pandemic. It may be the case that participating in the program helped participants remain on a path toward health and weight maintenance. However, without a control group or multiple baseline design, it is not possible to state this with certainty.

The staff and parents provided several ideas for program improvement. These included having more live cooking demonstrations, either in person or via videos. Also, according to the staff, in the future, it will be important to cook together and sample the healthy foods that are prepared during group. Exercising with the participants and following the exercises developed by their physical therapist stopped during the pandemic. In the future, it will be important to determine if the exercise partnership is improving engagement in exercises, and whether the participants are engaging in the exercises suggested by the physical therapist at home.

\section{Limitations and Future Directions}

Several factors limit the generalizability of this pilot study. As previously stated, without controls, through other participants not receiving the intervention or a multiple baseline design, it is not possible to say whether the intervention was successful. Hence, the information in this paper is preliminary and exploratory. Only a select group of parents/caregivers responded to surveys, and it may be that the program was only successful for about a third of the sample; however, staff and young adults in the program reported feeling positive about the program, and both reported behavior change. Another limitation was switching programming; however, the break in programming during the pandemic provided a gap in lessons, making the switch to presenting healthy lessons using MyPlate easier. Data were self-reported, and observational data and food and physical activity records will be needed in the future. Without an objective assessment of eating behaviors (e.g., use of food diaries or observations of meals) and without the use of pedometers or activity diaries, we cannot be certain that eating and exercise behaviors changed, and confirmatory evidence from additional measures is needed in future research.

The programming for MyPlate, portion control, learning food groups, and information about exercise and how exercise benefits health were well accepted by young adults, parents, and staff. Data from staff implementation logs indicated that programming was implemented as planned and was positively contributing to educational efforts for the young adults. Having an advisory committee to help guide programming efforts and select study measures may enhance the "fit" of the research and assessment tools to the needs of the young adults. It would be advisable to have an advisory committee review other programs, which have been successful in improving weight loss and health of individuals with developmental disabilities (e.g., Bedard et al., 2021; Myers et al., 2018; Shlesinger et al., 2018; Singh et al., 2008). Incorporating ideas from other successful programs has the potential to strengthen education, and subsequently behavior change. Moreover, assessment of change over time, using observations and more objective assessment tools, with breaks in program delivery to determine if knowledge and behavior change generalizes when the program is not in place, will provide further data about how and whether the program works. Studies with control groups and random assignment to intervention and control conditions would allow for assessment of intervention effectiveness in promoting weight loss and behavior change. Researchers could examine whether involving parents in programming, with parents selecting family goals, would result in higher levels of change in eating and exercise behaviors compared to teaching young adults and having them select their goals without parent involvement. Additionally, conducting qualitative studies, to examine which parts of programming are most helpful for those with different types of developmental disabilities, will provide information to tailor interventions. Understanding what works for whom and how, and how behaviors are changed at home, will add more knowledge to a growing literature to prevent obesity and improve health outcomes for young adults with ASD and IDs. 
Acknowledgements The authors would like to thank Katie Hamblin for working with participants and assisting the team. The authors would like to thank Tabitha Naa Akuyea Addy for her suggestions and feedback.

Author Contribution LN contributed to conceptualization, design, intervention, development of results, writing of this study, and editing the final manuscript. AO contributed to the design and intervention and wrote part of the results for this study. CC contributed to the conceptualization, design, and writing of this study. KA contributed to the evaluation of results, development of the paper, and writing of this study, and editing of the final manuscript.

\section{Declarations}

Ethics Approval Approval was obtained from the ethics committee of University Cincinnati. The procedures used in this study adhere to the tenets of the Declaration of Helsinki.

Informed Consent Verbal informed consent was obtained prior to the intervention, interviews, and surveys.

Conflict of Interest The authors declare no competing interests.

\section{References}

Abughosh, S. M., Vadhariya, A., Johnson, M. L., Essien, E. J., Esse, T. W., Serna, O., Gallardo, E., Boklage, S. H., Choi, J., Holstad, M. M., \& Fleming, M. L. (2019). Enhancing statin adherence using a motivational interviewing intervention and past adherence trajectories in patients with suboptimal adherence. Journal of Managed Care \& Specialty Pharmacy, 25(10), 1053-1062. https://doi.org/ 10.18553/jmcp.2019.25.10.1053

Bedard, K. E., Griffith, A. K., Lister, M. A., \& Swain, M. A. (2021). Behavioral and dietary management for adults with PraderWilli Syndrome in a residential setting. Advances in Neurodevelopmental Disorders, 5(1), 93-101. https://doi.org/10.1007/ s41252-020-00185-4

Burke, K. M., Raley, S. K., Shogren, K. A., Hagiwara, M., MumbardóAdam, C., Uyanik, H., \& Behrens, S. (2020). A meta-analysis of interventions to promote self-determination for students with disabilities. Remedial and Special Education, 41(3), 176-188. https://doi.org/10.1177/0741932518802274

Carr, K. A., \& Epstein, L. H. (2020). Choice is relative: Reinforcing value of food and activity in obesity treatment. American Psychologist, 75(2), 139-151. https://doi.org/10.1037/amp0000521

Croen, L. A., Zerbo, O., Qian, Y., Massolo, M. L., Rich, S., Sidney, S., \& Kripke, C. (2015). The health status of adults on the autism spectrum. Autism : The International Journal of Research and Practice, 19(7), 814-823. https://doi.org/10.1177/1362361315 577517

Davignon, M. N., Qian, Y., Massolo, M., \& Croen, L. A. (2018). Psychiatric and medical conditions in transition-aged individuals with ASD. Pediatrics, 141(Suppl 4), S335-S345. https://doi.org/10. 1542/peds.2016-4300K

Donabedian, A. (1966). Evaluating the quality of medical care. The Milbank Memorial Fund Quarterly, 44(3), 166-206 http://www. jstor.org/stable/3348969

Draheim, C. C., Williams, D. P., \& McCubbin, J. A. (2002). Physical activity, dietary intake, and the insulin resistance syndrome in nondiabetic adults with mental retardation. American Journal of Mental Retardation, 107(5), 361-375.

Epstein, L. H. (2005). The Traffic Light Childhood Weight Control Program: Traffic Light: Kid's Program. University of Buffalo, NY: Author.

Gelbar, N., Madaus, J. W., Dukes, L., Faggella-Luby, M., Volk, D., \& Monahan, J. (2020). Self-determination and college students with disabilities: Research trends and construct measurement. Journal of Student Affairs Research and Practice, 57(2), 163-181. https:// doi.org/10.1080/19496591.2019.1631835

Grumstrup, B., \& Demchak, M. (2017). Obesity, nutrition, and physical activity for people with significant disabilities. Physical Disabilities: Education and Related Services, 36(1), 13-28. https://doi. org/10.14434/pders.v36i1.23144

Harris, L., Hankey, C., Jones, N., Pert, C., Murray, H., Tobin, J., Boyle, S., \& Melville, C. (2017). A cluster randomised control trial of a multi-component weight management programme for adults with intellectual disabilities and obesity. British Journal of Nutrition, 118(3), 229-240. https://doi.org/10.1017/S0007114517001933

Hsieh, K., Rimmer, J. H., \& Heller, T. (2014). Obesity and associated factors in adults with intellectual disability. Journal of Intellectual Disability Research, 58(9), 851-863. https://doi.org/10.1111/jir. 12100

LaBrie, J. W., Thompson, A. D., Huchting, K., Lac, A., \& Buckley, K. (2007). A group Motivational Interviewing intervention reduces drinking and alcohol-related negative consequences in adjudicated college women. Addictive behaviors, 32(11), 2549-2562. https:// doi.org/10.1016/j.addbeh.2007.05.014

Li, Y.-J., Xie, X.-N., Lei, X., Li, Y.-M., \& Lei, X. (2020). Global prevalence of obesity, overweight and underweight in children, adolescents and adults with autism spectrum disorder, attention-deficit hyperactivity disorder: A systematic review and meta-analysis. Obesity Reviews, 21(12), e13123. https://doi.org/10.1111/obr. 13123

Melville, C. A., Boyle, S., Miller, S., Macmillan, S., Penpraze, V., Pert, C., Spanos, D., Matthews, L., Robinson, N., Murray, H., \& Hankey, C. R. (2011). An open study of the effectiveness of a multi-component weight-loss intervention for adults with intellectual disabilities and obesity. British Journal of Nutrition, 105(10), 1553-1562. https://doi.org/10.1017/S0007114510005362

Miller, W. R., \& Rollnick, S. (2002). Motivational interviewing: Preparing people for change (2nd ed.). Guilford Press.

Myers, R. E., Karazsia, B. T., Kim, E., Jackman, M. M., McPherson, C. L., \& Singh, N. N. (2018). A telehealth parent-mediated mindfulness-based health wellness intervention for adolescents and young adults with intellectual and developmental disabilities. Advances in Neurodevelopmental Disorders, 2(3), 241-252. https://doi.org/ 10.1007/s41252-018-0060-x

Ptomey, L. T., Saunders, R. R., Saunders, M., Washburn, R. A., Mayo, M. S., Sullivan, D. K., Gibson, C. A., Goetz, J. R., Honas, J. J., Willis, E. A., Danon, J. C., Krebill, R., \& Donnelly, J. E. (2018). Weight management in adults with intellectual and developmental disabilities: A randomized controlled trial of two dietary approaches. Journal of Applied Research in Intellectual Disabilities, 31(Suppl 1), 82-96. https://doi.org/10.1111/jar.12348

Ptomey, L. T., Sullivan, D. K., Lee, J., Goetz, J. R., Gibson, C., \& Donnelly, J. E. (2015). The use of technology for delivering a weight loss program for adolescents with intellectual and developmental disabilities. Journal of the Academy of Nutrition and Dietetics, 115(1), 112-118. https://doi.org/10.1016/j.jand.2014.08.031

Ptomey, L. T., Walpitage, D. L., Mohseni, M., Dreyer Gillette, M. L., Davis, A. M., Forseth, B., Dean, E. E., \& Waitman, L. R. (2020). Weight status and associated comorbidities in children and adults with Down syndrome, autism spectrum disorder and intellectual and developmental disabilities. Journal of Intellectual Disability Research, 64(9), 725-737. https://doi.org/10.1111/jir.12767 
Schaefer, M. R., \& Kavookjian, J. (2017). The impact of motivational interviewing on adherence and symptom severity in adolescents and young adults with chronic illness: A systematic review. Patient Education and Counseling, 100(12), 2190-2199. https:// doi.org/10.1016/j.pec.2017.05.037

Shlesinger, A., Bird, F., Duhanyan, K., Harper, J. M., \& Luiselli, J. K. (2018). Evaluation of a comprehensive health-wellness intervention on weight and BMI of residential students with neurodevelopmental disorders. Advances in Neurodevelopmental Disorders, 2(4), 425-432. https://doi.org/10.1007/s41252-018-0081-5

Shogren, K. A., Burke, K. M., Antosh, A., Wehmeyer, M. L., LaPlante, T., Shaw, L. A., \& Raley, S. (2019). Impact of the Self-Determined Learning Model of Instruction on self-determination and goal attainment in adolescents with intellectual disability. Journal of Disability Policy Studies, 30(1), 22-34. https://doi.org/10.1177/ 1044207318792178

Singh, N. N., Lancioni, G. E., Singh, A. N., Winton, A. S., Singh, J., McAleavey, K. M., \& Adkins, A. D. (2008). A mindfulnessbased health wellness program for an adolescent with Prader-Willi syndrome. Behavior modification, 32(2), 167-181. https://doi.org/ 10.1177/0145445507308582

Weems, M., Truex, L., Scampini, R., Fleming, R., Curtin, C., \& Bandini, L. (2017). A novel weight-loss tool designed for adolescents with intellectual disabilities. Journal of the Academy of Nutrition and Dietetics, 117(10), 1503-1508. https://doi.org/10.1016/j.jand. 2016.09.006

Zheng, Z., Zhang, L., Li, S., Zhao, F., Wang, Y., Huang, L., Huang, J., Zou, R., Qu, Y., \& Mu, D. (2017). Association among obesity, overweight and autism spectrum disorder: A systematic review and meta-analysis. Scientific Reports, 7(1), 11697. https://doi.org/ 10.1038/s41598-017-12003-4

Publisher's Note Springer Nature remains neutral with regard to jurisdictional claims in published maps and institutional affiliations. 